\title{
Hypnotics and Driving Safety: Meta-Analyses of Randomized Controlled Trials Applying the on-the-Road Driving Test
}

\author{
Joris C. Verster ${ }^{*}, 1$, Dieuwke S. Veldhuijzen ${ }^{1}$, Alain Patat $^{2}$, Berend Olivier ${ }^{1}$ and Edmund R. Volkerts ${ }^{1}$ \\ ${ }^{1}$ Utrecht Institute for Pharmaceutical Sciences, Department of Psychopharmacology, University of Utrecht, PO BOX \\ 80082, 3508 TB, Utrecht, The Netherlands \\ ${ }^{2}$ Wyeth Research, Clinical Pharmacology, Paris, France
}

\begin{abstract}
Background: Many people who use hypnotics are outpatients and are likely to drive a car the day after drug intake. The purpose of these meta-analyses was to determine whether or not this is safe.

Methods: Placebo-controlled, randomized, double-blind trials were selected if using the on-the-road driving test to determine driving ability the day following one or two nights of treatment administration. Primary outcome measure of the driving test was the Standard Deviation of Lateral Position (SDLP); i.e., the weaving of the car. Fixed effects model meta-analyses were performed. Effect size (ES) was computed using mean standardized (weighted) difference scores between treatment and corresponding placebo SDLP values.

Results: Ten studies, published from 1984 to 2002 (207 subjects), were included in the meta-analyses. The morning following bedtime administration, i.e. 10-11 hours after dosing, significant driving impairment was found for the recommended dose of various benzodiazepine hypnotics $(\mathrm{ES}=0.42 ; 95 \%$ Confidence Interval $(\mathrm{CI})=0.14$ to 0.71$)$. Twice the recommended dose impaired driving both in the morning ( $\mathrm{ES}=0.68 ; \mathrm{CI}=0.39$ to 0.97 ) and afternoon, i.e. $16-17$ hours after dosing ( $\mathrm{ES}=0.57$; $\mathrm{CI}=0.26$ to 0.88 ). Zopiclone $7.5 \mathrm{mg}$ also impaired driving in the morning ( $\mathrm{ES}=0.89$; $\mathrm{CI}=0.54$ to 1.23). Zaleplon $(10$ and $20 \mathrm{mg})$ and zolpidem $(10 \mathrm{mg})$ did not affect driving performance the morning after dosing. Following middle-of-the-night administration, significantly impaired driving performance was found for zopiclone $7.5 \mathrm{mg}$ ( $\mathrm{ES}=1.51, \mathrm{CI}=0.85$ to 2.17$)$, zolpidem $10 \mathrm{mg}(\mathrm{ES}=0.66, \mathrm{CI}=0.13$ to 1.19$)$ and zolpidem $20 \mathrm{mg}(\mathrm{ES}=1.16, \mathrm{CI}=0.60$ to 1.72). Zaleplon (10 and $20 \mathrm{mg}$ ) did not affect driving performance.

Conclusions: The analyses show that driving a car the morning following nocturnal treatment with benzodiazepines and zopiclone is unsafe, whereas the recommended dose of zolpidem $(10 \mathrm{mg})$ and zaleplon $(10 \mathrm{mg})$ do not affect driving ability.
\end{abstract}

Keywords: Driving, hypnotics, benzodiazepines, zopiclone, zolpidem, zaleplon.

\section{INTRODUCTION}

Insomnia not only comprises sleep initiation problems, but also nightly and early morning awakenings. The majority of patients suffering from insomnia is treated in an outpatient setting and continue their daily activities, including driving a car.

Several surveys illustrate that insomnia must be viewed as a major public health problem. For example, according to the 2002 Sleep in America poll, 37\% of adults reported that daytime sleepiness interferes significantly with their daily activities [1]. Also, the National Sleep Foundation Gallup Survey revealed that 63 million adults have sleep levels considered hazardous to their well being, with $6 \%$ experiencing severe levels of sleepiness [2-3]. Benzodiazepine hypnotics are still the most commonly used psychoactive drugs to treat insomnia, but the use of so-called z-drugs (zopiclone, zolpidem and zaleplon) is rapidly increasing. This shift was initiated by the observation that benzodiazepines produce residual effects such as daytime

*Address correspondence to this author at the Utrecht Institute for Pharmaceutical Sciences, Department of Psychopharmacology, University of Utrecht, PO BOX 80082, 3508 TB, Utrecht, The Netherlands; Tel: +31 30253 6909; Fax: +31 30253 7387; E-mail: j.c.verster@pharm.uu.nl sleepiness and reduced alertness, whereas the ideal hypnotic should be devoid of these potentially performance-impairing adverse effects. Since most hypnotics are prescribed to outpatients that fully participate in society, much research has focused to examine the possible residual effects of hypnotics on daily activities such as driving a car.

In the 1980s, the on-the-road driving test was introduced to examine drug effects on driving ability [4]. Since this standardized driving test is conducted on a public highway during normal traffic, it is evident that this test has a high ecological validity relative to driving simulators and laboratory tests [5].

Recently, a systematic review was published summarizing the results from studies that examined the effects of hypnotics on driving ability using the on-the-road driving test [6]. The disadvantage of systematic reviews is that results from individual studies are discussed based upon their statistical significance. This may be misleading, since studies with small sample sizes may present data (drugversus-placebo differences) that are conflicting with those from larger studies. Nevertheless, these differences may be meaningful, and including small studies in a meta-analysis may change an overall conclusion based upon large studies only. Combining the results from a number of smaller studies in a meta-analysis will take into account the observed 
effects, weighing them for their effect size, and produce a synthesized effect estimate with considerable power [7].

Based upon the conclusions from our recent literature review [6], a series of meta-analyses was conducted to test the following hypotheses:

1. Do hypnotics impair driving ability in the morning (10 - 11 hours after bedtime administration)?

2. Do hypnotics impair driving ability in the afternoon (16 - 17 hours after bedtime administration)?

3. Do hypnotics impair driving ability in the morning, (4 -6 hours after middle-of-the-night administration)?

To address these hypotheses, different meta-analyses were performed for:

1. benzodiazepines (recommended dose, or twice the recommended dose)

2. zopiclone (recommended dose, $7.5 \mathrm{mg}$ )

3. zolpidem (recommended dose, $10 \mathrm{mg}$, or twice the recommended dose, $20 \mathrm{mg}$ )

4. zaleplon (recommended dose, $10 \mathrm{mg}$, or twice the recommended dose, $20 \mathrm{mg}$ )

\section{METHODS}

\section{Literature Search and Study Selection}

A literature search including MEDLINE and EMBASE was performed (key words: driving, combined with hypnotic, benzodiazepine, zaleplon, zopiclone, zolpidem) and crossreferences were consulted to determine all studies examining the effects of hypnotics on driving ability. Studies were selected if the following inclusion criteria were met: (1) the on-the-road driving test was used to determine driving ability, (2) the study was placebo controlled, crossover and double-blind, (3) tests were performed the day following one or two nights of treatment administration, (4) treatments were administered at bedtime or during the night, (5) subjects were healthy volunteers (with or without a history of transient insomnia), and (6) subjects did not use hypnotics or other drugs that are known to affect driving ability at the time of study participation.

\section{The on-the-Road Driving Test}

All studies used the same standardized on-the-road driving test during normal traffic (see Fig. 1) [6]. Subjects are instructed to drive a car over a public highway circuit (usually $100-\mathrm{km}$ ) with a constant speed $(90-95 \mathrm{~km} / \mathrm{h}$ ) and a steady lateral position within the right (slower) traffic lane. A licensed driving instructor who is equipped with dual controls accompanies the subject to guard his/her safety. The primary parameter of the test is the Standard Deviation of Lateral Position (SDLP, cm), the weaving of the car.

From Fig. 1 (top), it can be seen that twice a second the lateral position of the car relative to the lane boundary is recorded. Then, over the $100 \mathrm{~km}$ test, the overall mean lateral position is computed (Fig.1, middle). The standard deviation of the mean lateral position is the SDLP. From Fig. 1 (bottom) it is evident that SDLP represents the amount of vehicle control. Highly elevated SDLP (gross weaving of the car) may result in excursions out of lane, both into the road shoulder and/or the adjacent traffic lane. Hence, high SDLP values represent unsafe driving behavior.

A closed road study to calibrate the on-the-road driving test methodology showed that most participants had an SDLP value between 18 and $22 \mathrm{~cm}$ in the placebo condition [8]. For different dosages of alcohol, SDLP increments were observed in a dose-related manner. An SDLP increment of $2.4 \mathrm{~cm}$, found after administration of alcohol to reach a blood alcohol concentration of $0.05 \%$ (the legal limit for driving in most countries), is considered as a clinical relevant change from baseline (placebo).

\section{Statistical Analysis}

Statistical analyses were performed using Comprehensive Meta-analysis, a computer program for research synthesis [9]. The effect size (ES) for each treatment-versus-placebo comparison was calculated, using standardized mean SDLP differences. That is, when computing the effect size, SDLP differences between treatment and placebo were weighted according to the number of subjects that participated in each study. In addition, the ninety-five percent confidence interval ( $95 \%$ CI) was computed for each ES. If the confidence interval does not include zero, the ES is statistically significant.

First, because the unit of analysis in a meta-analysis is the individual research study, in each meta-analysis only one treatment-versus-placebo comparison was included from each study (Comparisons that come from the same study are statistically dependent). Second, the aim was to include a specific treatment-versus-placebo comparison only once in each analysis. Thus, for example, a second lormetazepamversus-placebo comparison was not included when a unique oxazepam-versus-placebo comparison could be included.

Homogeneity/heterogeneity analyses were performed to determine if all individual ES have the same distribution as the combined overall ES. In a homogenous distribution, the dispersion of effect sizes around their mean is not greater than that expected from sampling error alone. If the $\mathrm{Q}$ statistic resulting from this analysis is not significant $(\mathrm{p}>$ 0.05 ), a homogenous distribution can be assumed and using a fixed effects model to perform the meta-analysis is justified. However, if the Q statistic is significant $(\mathrm{p}<0.05)$, variation in effect size is greater than would be expected from subject-level sampling error alone, and a random effects model should be applied correcting for additional variation between the studies [7].

\section{RESULTS}

\section{Selected Studies and Subjects}

Ten studies [10-18] (labeled Study 1-10 in the text and Tables) were identified that met all inclusion criteria for the meta-analyses. Study characteristics are summarized in Table 1.

All on-the-road driving studies have been performed in The Netherlands (Universities of Groningen, Maastricht or Utrecht). Six studies [10-14] (Study 1-6) were performed in the 1980s and examined the effects of benzodiazepines and zopiclone after two nights of bedtime administration. Three studies [15-17] (Study 7-9) examined the effects of 
The instrumented test vehicle has a camera for lateral position meas urements. The camera is equipped with two infrared lights, to enable recording during the night and dark weather circumstances. $D$ ata (speed and lateral position) are continuously recorded on a board computer with a sampling rate of 2 $H z$. The raw data is edited off-line to remove dat a that were disturbed by extraneous events (e.g. overtaking and traffic jams).
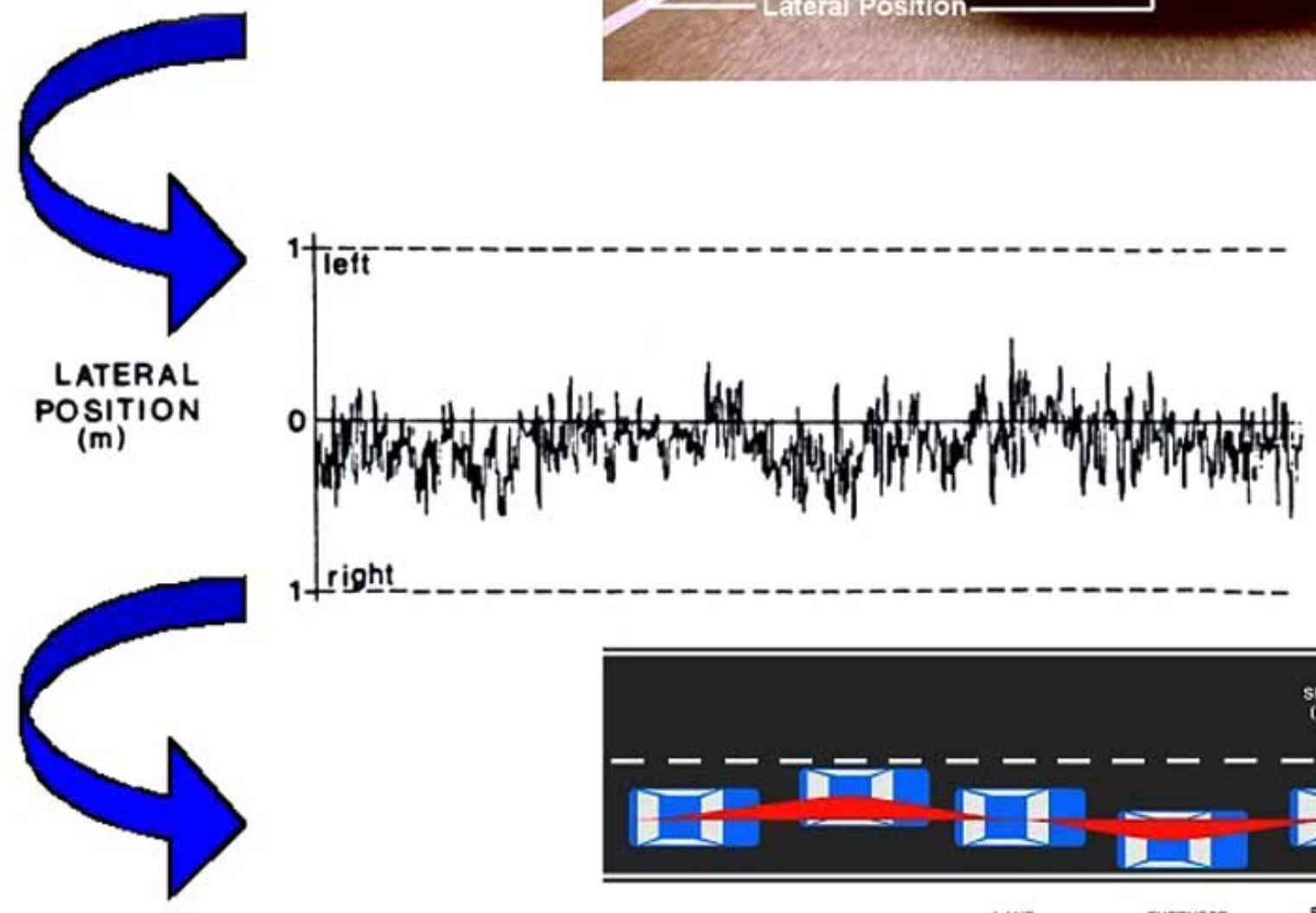

The Standard Deviation of Lateral Position (SDLP) is computed, expressing the weaving of the car.
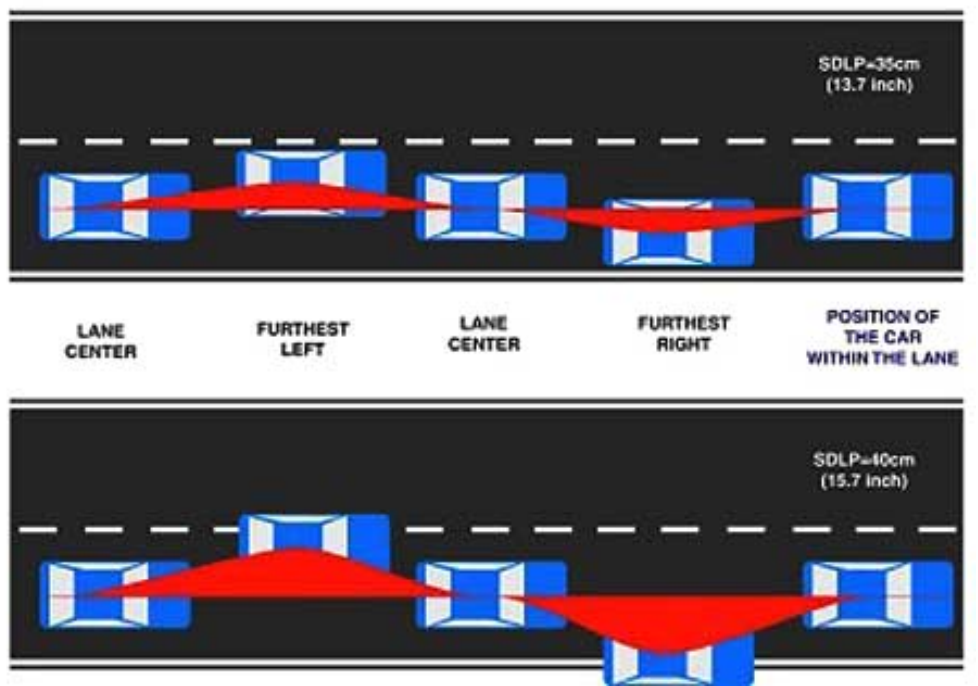

Fig (1). The on-the-road driving test. 
Table 1. Study Characteristics

\begin{tabular}{|c|c|c|c|c|c|}
\hline $\begin{array}{l}\text { Study } \\
\text { [ref.] }\end{array}$ & Subjects & $\begin{array}{l}\text { Age } \\
\text { (SD) }\end{array}$ & Nights & Treatment & Outcome \\
\hline $\begin{array}{c}1 \\
{[10]}\end{array}$ & $\begin{array}{l}24 \text { women with a history } \\
\text { of insomnia and hypnotic } \\
\text { treatment }\end{array}$ & $\begin{array}{l}28.6 \\
(4.0)\end{array}$ & 2 & $\begin{array}{c}\text { flurazepam } 15 \text { en } 30 \mathrm{mg} \\
\text { secobarbital } 200 \mathrm{mg} \\
\text { placebo }\end{array}$ & $\begin{array}{c}\text { SDLP was significantly increased after flurazepam } \\
(15 \text { and } 30 \mathrm{mg}) \text { and secobarbital } 10-11 \mathrm{~h} \text { and } 16-17 \mathrm{~h} \\
\text { after administration. }\end{array}$ \\
\hline $\begin{array}{c}2 \\
{[10,19]}\end{array}$ & $\begin{array}{l}16 \text { women with a history } \\
\text { of insomnia and hypnotic } \\
\text { treatment }\end{array}$ & $\begin{array}{l}28.7 \\
(4.8)\end{array}$ & 2 & $\begin{array}{l}\text { loprazolam } 1 \text { and } 2 \mathrm{mg} \\
\text { flunitrazepam } 2 \mathrm{mg} \\
\text { placebo }\end{array}$ & $\begin{array}{l}\text { SDLP was significantly increased } 10-11 \mathrm{~h} \text { and } 16- \\
17 \mathrm{~h} \text { after Flunitrazepam and loprazolam } 2 \mathrm{mg} \\
\text { administration. Loprazolam } 1 \mathrm{mg} \text { significantly } \\
\text { increased SDLP } 10-11 \mathrm{~h} \text { after administration, but not } \\
\text { in the afternoon. }\end{array}$ \\
\hline $\begin{array}{c}3 \\
{[11]}\end{array}$ & $\begin{array}{l}16 \text { women with a history } \\
\text { of insomnia and hypnotic } \\
\text { treatment }\end{array}$ & $\begin{array}{l}29.1 \\
(4.7)\end{array}$ & 2 & $\begin{array}{l}\text { zopiclone } 7.5 \mathrm{mg} \\
\text { nitrazepam } 5 \mathrm{mg} \\
\text { flunitrazepam } 2 \mathrm{mg} \\
\text { placebo }\end{array}$ & $\begin{array}{l}\text { SDLP was significantly increased } 10-11 \mathrm{~h} \text { and } 16- \\
17 \mathrm{~h} \text { after Flunitrazepam } 2 \mathrm{mg} \text {. SDLP was } \\
\text { significantly increased } 10-11 \mathrm{~h} \text { after zopiclone } 7.5 \\
\text { mg administration, but not in the afternoon. } \\
\text { Nitrazepam } 5 \mathrm{mg} \text { did not impair driving ability. }\end{array}$ \\
\hline $\begin{array}{c}4 \\
{[12,20]}\end{array}$ & $\begin{array}{l}12 \text { women with a history } \\
\text { of insomnia and hypnotic } \\
\text { treatment }\end{array}$ & $\begin{array}{l}32.9 \\
(3.8)\end{array}$ & 2 & $\begin{array}{l}\text { temazepam } 20 \mathrm{mg} \text { (caps.) } \\
\text { nitrazepam } 10 \mathrm{mg} \\
\text { placebo }\end{array}$ & $\begin{array}{l}\text { Temazepam did not significantly impair driving } \\
\text { ability. SDLP was significantly increased after } \\
\text { Nitrazepam } 10 \mathrm{mg} \text {. The effects of Nitrazepam were } \\
\text { most pronounced in the afternoon test. }\end{array}$ \\
\hline $\begin{array}{c}5 \\
{[13,21]}\end{array}$ & $\begin{array}{l}16 \text { healthy volunteers with } \\
\text { a history of insomnia and } \\
\text { hypnotic treatment ( } 6 \text { men } \\
\text { and } 10 \text { women) }\end{array}$ & $26-41$ & 2 & $\begin{array}{l}\text { lormetazepam } 1 \mathrm{mg} \text { and } \\
\qquad 2 \mathrm{mg} \text { (caps.) } \\
\text { flurazepam } 30 \mathrm{mg} \\
\text { placebo }\end{array}$ & $\begin{array}{c}\text { Driving ability was not significantly impaired after } \\
\text { lormetazepam } 1 \mathrm{mg} \text { and } 2 \mathrm{mg} \text {. Flurazepam } 30 \mathrm{mg} \\
\text { significantly impaired driving ability. }\end{array}$ \\
\hline $\begin{array}{c}6 \\
{[14,22]}\end{array}$ & 18 male healthy volunteers & $\begin{array}{l}26.3 \\
(1.6)\end{array}$ & 2 & $\begin{array}{l}\text { lormetazepam } 1 \mathrm{mg} \\
\text { oxazepam } 50 \mathrm{mg} \\
\text { placebo }\end{array}$ & $\begin{array}{l}\text { In the morning, SDLP was significantly increased } \\
\text { after both lormetazepam } 1 \mathrm{mg} \text { and oxazepam } 50 \mathrm{mg} \text {. } \\
\text { Driving was not significantly impaired in the } \\
\text { afternoon. }\end{array}$ \\
\hline $\begin{array}{c}7 \\
{[15]}\end{array}$ & $\begin{array}{l}17 \text { female subjects with a } \\
\text { history of insomnia and } \\
\text { hypnotic treatment }\end{array}$ & $\begin{array}{l}40.8 \\
(7.2)\end{array}$ & 1 & $\begin{array}{c}\text { zolpidem } 10 \mathrm{mg} \\
\text { flunitrazepam } 2 \mathrm{mg} \\
\text { partial sleep deprivation } \\
\text { placebo }\end{array}$ & $\begin{array}{l}\text { 10-11 hours after bedtime administration, } \\
\text { SDLP did not differ significantly from placebo after } \\
\text { zolpidem and flunitrazepam. Also, partial sleep } \\
\text { deprivation did not affect driving performance. }\end{array}$ \\
\hline $\begin{array}{c}8 \\
{[16]}\end{array}$ & $\begin{array}{c}28 \text { healthy volunteers ( } 14 \\
\text { men and } 14 \text { women) }\end{array}$ & $\begin{array}{l}31.0 \\
(5.7)\end{array}$ & 1 & $\begin{array}{c}\text { zaleplon } 10 \mathrm{mg} \text { and } 20 \mathrm{mg} \\
\text { zopiclone } 7.5 \mathrm{mg} \\
\text { placebo }\end{array}$ & $\begin{array}{c}\text { Zopiclone significantly increased SDLP and SD } \\
\text { speed 5-6h after administration; SDLP was also } \\
\text { significantly elevated } 11 \mathrm{~h} \text { after administration. } \\
\text { Driving performance after both doses of zaleplon } \\
\text { matched placebo. }\end{array}$ \\
\hline $\begin{array}{c}9 \\
{[17]}\end{array}$ & $\begin{array}{l}30 \text { healthy volunteers ( } 15 \\
\text { men and } 15 \text { women) }\end{array}$ & $\begin{array}{l}31.6 \\
(6.9)\end{array}$ & 1 & $\begin{array}{c}\text { zopiclone } 7.5 \mathrm{mg} \\
\text { zaleplon } 10 \mathrm{mg} \\
\text { placebo } \\
\text { alcohol }(\mathrm{BAC}<0.05 \%)\end{array}$ & $\begin{array}{c}\text { Zopiclone significantly impaired driving ability, } 10 \mathrm{~h} \\
\text { after bedtime administration. Alcohol also } \\
\text { significantly impaired driving performance. } \\
\text { Zaleplon did not affect driving. }\end{array}$ \\
\hline $\begin{array}{c}10 \\
{[18]}\end{array}$ & $\begin{array}{c}30 \text { healthy volunteers (15 } \\
\text { men and } 15 \text { women) }\end{array}$ & $\begin{array}{l}24.0 \\
(2.4)\end{array}$ & 1 & $\begin{array}{l}\text { zaleplon } 10 \mathrm{mg} \text { and } 20 \mathrm{mg} \\
\text { zolpidem } 10 \mathrm{mg} \text { and } 20 \mathrm{mg} \\
\text { placebo } \\
\text { alcohol }(\mathrm{BAC}<0.05 \%)\end{array}$ & $\begin{array}{l}\text { Zolpidem (10 and } 20 \mathrm{mg}) \text { and alcohol significantly } \\
\text { impaired driving ability } 4-5 \mathrm{~h} \text { after middle-of-the- } \\
\text { night administration. Zaleplon } 10 \mathrm{mg} \text { and } 20 \mathrm{mg} \text { did } \\
\text { not affect driving ability. }\end{array}$ \\
\hline
\end{tabular}

zopiclone, zolpidem and zaleplon after one night of bedtime administration. Two studies [16,18] (Study 8 and 10) also examined zolpidem and zaleplon after middle-of-the-night administration.

The evaluated benzodiazepine hypnotics (recommended dose) were: nitrazepam $(5 \mathrm{mg})$, flurazepam $(15 \mathrm{mg})$, flunitrazepam (2 mg), loprazolam (1 mg), lormetazepam (1 $\mathrm{mg}$ ), oxazepam (50 mg) and temazepam $(20 \mathrm{mg})$.

In all studies, subjects were trained to become familiar with the vehicle and testing procedures. All studies used the same standardized driving test over a public highway during normal traffic. Tests were performed in the morning, i.e. 10-
11 hours after dosing (Study 1-10) [10-18], or in the afternoon, i.e. 16-17 hours after dosing (Study 1-6) [10-14].

A total of 207 healthy volunteers participated in ten onthe-road studies. In studies 1-4 and 7, all subjects were females. In study 6 , the subjects were men. In studies 5 and $8-10$, both men and women were included. In studies 6 and $8-10$, healthy volunteers had no past experience of insomnia or hypnotic drug use. In studies 1-5 and 7, subjects were former users of hypnotic drugs for the treatment of insomnia. They were selected based upon the knowledge that the majority of insomniacs are women. In addition, the investigators wanted to be sure that subjects would be 
responsive to hypnotic treatment (as was evident from their successful use in the past). The majority of these women were housewives, who were successfully treated with a benzodiazepine drug (mostly nitrazepam) for transient insomnia caused by unfortunate life events such as divorce. At the time of study participation, these problems and accompanying sleep disturbances were solved and they can thus be regarded as healthy volunteers.

In conclusion, all subjects that participated in these ten studies did not use hypnotics or other psychoactive medication at the time of study participation and were free from sleep disturbances. They possessed a valid drivers license for at least 3 years, and drove at least $5000 \mathrm{~km}$ yearly.

\section{Effect Sizes and Significance}

Effect size, 95\% CI, and statistical significance were computed for each treatment-versus-placebo comparison. To calculate the effect size, mean, standard deviation and sample size were obtained from the publication $[15,17,18]$ (Studies 7, 9 and 10), accompanying technical reports [11,19-22] (Studies 2-6), raw data files (Study 1), or were obtained from the study sponsor (Study 8, Wyeth Research). The effect size, $95 \%$ CI, and the statistical significance for each treatment-versus-placebo comparison is summarized in Table 2.

\section{Data Selection}

In the meta-analysis for benzodiazepines (recommended dose), regarding Study 6, a choice had to be made whether to include data of lormetazepam or oxazepam. The oxazepam condition was chosen, since lormetazepam was already included from Study 5. In line, in the analysis for benzodiazepines (twice the recommended dose) loprazolam from Study 2 and lormetazepam from study 5 were chosen.

For all meta-analyses, the Q statistic from the homogeneity analysis was not significant $(\mathrm{p}>0.05)$. Therefore, a homogenous distribution can be assumed and a fixed effects model was used. Results from the metaanalyses are summarized in Fig. 2.

\section{Driving Performance in the Morning (10-11 Hours After Bedtime Administration)}

Benzodiazepine hypnotics administered at bedtime cause significant driving impairment the following morning, both after intake of the recommended dose $(\mathrm{ES}=0.42 ; \mathrm{CI}=0.14$ to 0.71$)$ and twice the recommended dose $(\mathrm{ES}=0.68 ; \mathrm{CI}=$ 0.39 to 0.97$)$. Significant driving impairment was also observed the morning following bedtime administration of the recommended dose of zopiclone $(\mathrm{ES}=0.89 ; \mathrm{CI}=0.54$ to 1.23). In contrast, driving performance after the recommended dose $(10 \mathrm{mg})$ of zolpidem $(\mathrm{ES}=0.08$; $\mathrm{CI}=-$ 0.62 to 0.77$)$ and zaleplon $(\mathrm{ES}=0.07, \mathrm{CI}=-0.31$ to 0.45$)$ was not significantly different from placebo. Also, the morning following twice the recommended dose of zaleplon $(20 \mathrm{mg})$, driving performance did not differ from placebo (ES = $0.23, \mathrm{CI}=-0.82$ to 0.35 ). Zolpidem $20 \mathrm{mg}$, twice the recommended dose, has not been tested the morning following bedtime administration.

\section{Driving Performance in the Afternoon (16-17 Hours After Bedtime Administration)}

Benzodiazepine hypnotics administered at bedtime produce significant driving impairment in the afternoon after taking twice the recommended dose $(\mathrm{ES}=0.57, \mathrm{CI}=0.26$ to 0.88 ), but not after intake of the recommended dose (ES = $0.14, \mathrm{CI}=-0.14$ to 0.41$)$. Also, zopiclone $(7.5 \mathrm{mg})$ does not significantly impair driving performance in the afternoon $(\mathrm{ES}=0.25, \mathrm{CI}=-0.47$ to 0.98$)$. Zolpidem and zaleplon have not been tested in the afternoon.

\section{Driving Performance After Middle-of-the-Night Administration}

In the morning, significant driving impairment was found after middle-of-the-night intake of the recommended dose of zopiclone $(\mathrm{ES}=1.51, \mathrm{CI}=0.85$ to 2.17$)$. Also, both the recommended dose of zolpidem $(\mathrm{ES}=0.66, \mathrm{CI}=0.13$ to $1.19)$ and twice the recommended dose of zolpidem (ES = $1.16, \mathrm{CI}=0.60$ to 1.72 ) significantly impaired driving performance. In contrast, driving performance after both the recommended dose of zaleplon (ES $=-0.03, \mathrm{CI}=-0.40$ to $0.35)$ and twice the recommended dose of zaleplon (ES = $0.10, \mathrm{CI}=-0.29$ to 0.48 ) did not significantly differ from placebo. Benzodiazepine hypnotics have not been tested the morning following middle-of-the-night administration.

\section{DISCUSSION}

The meta-analyses confirm previous claims $[6,23,24]$ that benzodiazepine hypnotics significantly impair driving ability. With twice the recommended dose of benzodiazepines, this impairment is still significant in the afternoon. Zopiclone also significantly impaired driving performance the morning following bedtime afdministration, but not in the afternoon. In contrast, zolpidem and zaleplon do not impair driving performance the morning following 1 night of treatment. Zaleplon is the only hypnotic that did not produce driving impairment after middle-of-the-night administration.

The analyses further show that dosage and time after administration determine the magnitude of driving impairment observed for benzodiazepine hypnotics.

Roadside surveys reported that a substantial number of patients use higher drug dosages than recommended, and a significant relationship has been demonstrated between culpability of traffic accidents and benzodiazepine concentrations found in the blood [25]. Hence, the observation that the administered dosage significantly correlates with the magnitude of driving impairment is rather worrisome. Taking into account that driving ability is already significantly impaired when using the recommended dose of benzodiazepines, physicians should caution their patients not to use higher dosages than recommended.

Possible explanations for the differences in impairment found with hypnotics may be found at the $\mathrm{GABA}_{\mathrm{A}}$ receptor level. Benzodiazepines and zopiclone bind nonselective to benzodiazepine receptor subtypes $\alpha_{1}$ and $\alpha_{2}$, whereas zolpidem and zaleplon prefer binding to the type $\alpha_{1}-\mathrm{GABA}_{\mathrm{A}}$ 
Table 2. Summary of the Study Results

Tested 10-11 hours after bedtime administration

\begin{tabular}{|c|c|c|c|c|c|c|c|c|c|c|}
\hline \multirow{2}{*}{ Study [ref.] } & \multirow{2}{*}{ Treatment } & \multicolumn{3}{|c|}{ Placebo } & \multicolumn{3}{|c|}{ Treatment } & \multicolumn{3}{|c|}{ Outcome } \\
\hline & & $\mathbf{N}$ & Mean & SD & $\mathbf{N}$ & Mean & SD & $p$ & $E S$ & $95 \% C I$ \\
\hline \multirow[t]{2}{*}{ Study $1[10]$} & Flurazepam $15 \mathrm{mg}$ & 24 & 19.91 & 4.78 & 24 & 23.38 & 5.71 & 0.03 & 0.65 & $0.05 ; 1.25$ \\
\hline & Flurazepam $30 \mathrm{mg}$ & 24 & 19.91 & 4.78 & 24 & 27.11 & 8.01 & $0.0 \mathrm{E}+01$ & 1.07 & $0.45 ; 1.70$ \\
\hline \multirow[t]{3}{*}{ Study $2[10,19]$} & Loprazolam $1 \mathrm{mg}$ & 16 & 18.92 & 4.62 & 16 & 20.96 & 5.12 & 0.25 & 0.41 & $-0.32 ; 1.14$ \\
\hline & Loprazolam $2 \mathrm{mg}$ & 16 & 18.92 & 4.62 & 16 & 26.09 & 6.78 & $0.0 \mathrm{E}+01$ & 1.21 & $0.41 ; 2.00$ \\
\hline & Flunitrazepam $2 \mathrm{mg}$ & 16 & 18.92 & 4.62 & 16 & 21.04 & 4.94 & 0.22 & 0.43 & $-0.30 ; 1.16$ \\
\hline \multirow[t]{3}{*}{ Study 3 [11] } & Nitrazepam $5 \mathrm{mg}$ & 16 & 20.54 & 3.33 & 16 & 20.96 & 4.16 & 0.76 & 0.11 & $-0.61 ; 0.83$ \\
\hline & Flunitrazepam 2 mg & 16 & 20.54 & 3.33 & 16 & 23.27 & 5.22 & 0.09 & 0.61 & $-0.13 ; 1.35$ \\
\hline & Zopiclone $7.5 \mathrm{mg}$ & 16 & 20.54 & 3.33 & 16 & 23.19 & 4.26 & 0.06 & 0.68 & $-0.07 ; 1.42$ \\
\hline \multirow[t]{2}{*}{ Study $4[12,20]$} & Temazepam $20 \mathrm{mg}$ & 12 & 22.42 & 3.99 & 12 & 23.14 & 5.76 & 0.73 & 0.14 & $-0.71 ; 0.99$ \\
\hline & Nitrazepam $10 \mathrm{mg}$ & 12 & 22.42 & 3.99 & 12 & 24.39 & 5 & 0.21 & 0.51 & $-0.35 ; 1.38$ \\
\hline \multirow[t]{3}{*}{ Study $5[13,21]$} & Lormetazepam $1 \mathrm{mg}$ & 14 & 18.5 & 3.61 & 14 & 19.1 & 3.71 & 0.67 & 0.16 & $-0.62 ; 0.94$ \\
\hline & Lormetazepam $2 \mathrm{mg}$ & 14 & 17.6 & 3.87 & 14 & 20 & 4.7 & 0.15 & 0.54 & $-0.25 ; 1.34$ \\
\hline & Flurazepam 30 mg & 15 & 18.5 & 3.92 & 15 & 21.4 & 5.54 & 0.11 & 0.59 & $-0.18 ; 1.35$ \\
\hline \multirow[t]{2}{*}{ Study $6[14,22]$} & Oxazepam 50 mg & 18 & 17.1 & 2.27 & 18 & 19.75 & 3.46 & 0.01 & 0.89 & $0.17 ; 1.60$ \\
\hline & Lormetazepam $1 \mathrm{mg}$ & 18 & 17.1 & 2.27 & 18 & 18.76 & 2.53 & 0.05 & 0.68 & $-0.02 ; 1.37$ \\
\hline \multirow[t]{2}{*}{ Study 7 [15] } & Flunitrazepam $2 \mathrm{mg}$ & 17 & 21.9 & 4 & 17 & 22.2 & 3.6 & 0.82 & 0.08 & $-0.62 ; 0.78$ \\
\hline & Zolpidem $10 \mathrm{mg}$ & 17 & 21.9 & 4 & 17 & 22 & 4 & 0.94 & 0.02 & $-0.67 ; 0.72$ \\
\hline \multirow[t]{3}{*}{ Study $8[16]$} & Zaleplon $10 \mathrm{mg}$ & 25 & 22.03 & 3.78 & 25 & 21.6 & 2.96 & 0.66 & -0.13 & $-0.69 ; 0.45$ \\
\hline & Zaleplon $20 \mathrm{mg}$ & 25 & 22.03 & 3.78 & 23 & 21.2 & 3.08 & 0.41 & 0.24 & $-0.82 ; 0.35$ \\
\hline & Zopiclone $7.5 \mathrm{mg}$ & 25 & 22.03 & 3.78 & 24 & 26.86 & 5.72 & $0.0 \mathrm{E}+01$ & 0.99 & $0.37 ; 1.60$ \\
\hline \multirow[t]{2}{*}{ Study 9 [17] } & Zaleplon $10 \mathrm{mg}$ & 30 & 18.2 & 2.69 & 30 & 18.9 & 3.23 & 0.37 & 0.23 & $-0.29 ; 0.75$ \\
\hline & Zopiclone $7.5 \mathrm{mg}$ & 30 & 18.2 & 2.69 & 30 & 21.6 & 4.31 & $0.0 \mathrm{E}+01$ & 0.93 & $0.39 ; 1.48$ \\
\hline
\end{tabular}

Tested 16-17 hours after bedtime administration

\begin{tabular}{|c|c|c|c|c|c|c|c|c|c|c|}
\hline \multirow{2}{*}{ Study [ref.] } & \multirow{2}{*}{ Treatment } & \multicolumn{3}{|c|}{ Placebo } & \multicolumn{3}{|c|}{ Treatment } & \multicolumn{3}{|c|}{ Outcome } \\
\hline & & $\mathbf{N}$ & Mean & SD & $\mathbf{N}$ & Mean & SD & $p$ & $E S$ & $95 \% C I$ \\
\hline \multirow[t]{2}{*}{ Study $1[10]$} & Flurazepam $15 \mathrm{mg}$ & 24 & 20.51 & 4.48 & 24 & 22.95 & 4.88 & 0.08 & 0.51 & $-0.08 ; 1.10$ \\
\hline & Flurazepam $30 \mathrm{mg}$ & 24 & 20.51 & 4.48 & 24 & 24.84 & 7.05 & 0.02 & 0.72 & $0.12 ; 1.32$ \\
\hline \multirow[t]{2}{*}{ Study $2[10,19]$} & Loprazolam $1 \mathrm{mg}$ & 16 & 19.17 & 4.23 & 16 & 20.79 & 5.83 & 0.38 & 0.31 & $-0.42 ; 1.04$ \\
\hline & Loprazolam $2 \mathrm{mg}$ & 16 & 19.17 & 4.23 & 16 & 23.77 & 6.59 & 0.03 & 0.81 & $0.06 ; 1.57$ \\
\hline \multirow[t]{3}{*}{ Study 3 [11] } & Nitrazepam 5 mg & 16 & 20.91 & 3.75 & 16 & 21.36 & 4.64 & 0.77 & 0.1 & $-0.62 ; 0.83$ \\
\hline & Flunitrazepam 2 mg & 16 & 20.91 & 3.75 & 16 & 23.53 & 5.07 & 0.11 & 0.57 & $-0.17 ; 1.31$ \\
\hline & Zopiclone $7.5 \mathrm{mg}$ & 16 & 20.91 & 3.75 & 16 & 21.95 & 4.12 & 0.46 & 0.26 & $-0.47 ; 0.98$ \\
\hline \multirow[t]{2}{*}{ Study $4[12,20]$} & Temazepam $20 \mathrm{mg}$ & 12 & 22.29 & 3.81 & 12 & 22.11 & 3.5 & 0.91 & -0.05 & $-0.89 ; 0.80$ \\
\hline & Nitrazepam $10 \mathrm{mg}$ & 12 & 22.29 & 3.81 & 12 & 25.72 & 4.33 & 0.05 & 0.81 & $-0.08 ; 1.69$ \\
\hline \multirow[t]{2}{*}{ Study $5[13,21]$} & Lormetazepam $1 \mathrm{mg}$ & 16 & 18.5 & 3.5 & 16 & 18.2 & 4.06 & 0.82 & -0.08 & $-0.80 ; 0.65$ \\
\hline & Lormetazepam $2 \mathrm{mg}$ & 15 & 19.2 & 3.98 & 15 & 19 & 5.27 & 0.91 & -0.04 & $-0.79 ; 0.71$ \\
\hline \multirow[t]{2}{*}{ Study $6[14,22]$} & Oxazepam $50 \mathrm{mg}$ & 18 & 17.56 & 2.82 & 18 & 17.13 & 2.83 & 0.65 & -0.15 & $-0.83 ; 0.53$ \\
\hline & Lormetazepam $1 \mathrm{mg}$ & 18 & 17.56 & 2.82 & 18 & 17.76 & 2.73 & 0.83 & 0.07 & $-0.61 ; 0.75$ \\
\hline
\end{tabular}

Tested 4-6 hours after middle-of-the-night administration

\begin{tabular}{|c|c|c|c|c|c|c|c|c|c|c|}
\hline \multirow{2}{*}{ Study [ref.] } & \multirow{2}{*}{ Treatment } & \multicolumn{3}{|c|}{ Placebo } & \multicolumn{3}{|c|}{ Treatment } & \multicolumn{3}{|c|}{ Outcome } \\
\hline & & $\mathbf{N}$ & Mean & SD & $\mathbf{N}$ & Mean & SD & $p$ & $E S$ & $95 \% C I$ \\
\hline \multirow[t]{3}{*}{ Study 8 [16] } & Zaleplon $10 \mathrm{mg}$ & 25 & 22.03 & 3.78 & 26 & 22.14 & 3.85 & 0.92 & -0.03 & $-0.54 ; 0.59$ \\
\hline & Zaleplon $20 \mathrm{mg}$ & 25 & 22.03 & 3.78 & 22 & 22.26 & 4.78 & 0.86 & -0.05 & $-0.54 ; 0.64$ \\
\hline & Zopiclone $7.5 \mathrm{mg}$ & 25 & 22.03 & 3.78 & 24 & 30.93 & 7.19 & $0.0 \mathrm{E}+01$ & 1.53 & $0.87 ; 2.19$ \\
\hline \multirow[t]{4}{*}{ Study 10 [18] } & Zaleplon $10 \mathrm{mg}$ & 30 & 17.5 & 4.2 & 30 & 17.2 & 4.1 & 0.78 & -0.07 & $-0.59 ; 0.45$ \\
\hline & Zaleplon $20 \mathrm{mg}$ & 30 & 17.5 & 4.2 & 30 & 18.1 & 4.6 & 0.6 & 0.13 & $-0.38 ; 0.65$ \\
\hline & Zolpidem $10 \mathrm{mg}$ & 30 & 17.5 & 4.2 & 30 & 2.3 & 6.7 & 0.01 & 0.67 & $0.14 ; 1.20$ \\
\hline & Zolpidem $20 \mathrm{mg}$ & 30 & 17.5 & 4.2 & 30 & 28.1 & 11.9 & $0.0 \mathrm{E}+01$ & 1.17 & $0.61 ; 1.74$ \\
\hline
\end{tabular}




\section{0 - 11 hours after bedtime administration}

\begin{tabular}{|c|c|c|c|c|c|c|c|c|c|c|}
\hline & N1 & N2 & Effect & Lower & Upper & PValue & -2.00 & -1.00 & 0.00 & 2.00 \\
\hline Benzodiazepines - SD & 100 & 100 & .42 & .14 & .71 & .00 & & & $\rightarrow-$ & \\
\hline Benzodiazepines - DD & 99 & 99 & .68 & .39 & .97 & .00 & & & $\rightarrow$ & \\
\hline Zolpidem $10 \mathrm{mg}$ & 17 & 17 & .08 & -.62 & .77 & .82 & & & & \\
\hline Zaleplon $10 \mathrm{mg}$ & 55 & 55 & .07 & -.31 & .45 & .71 & & & - & \\
\hline Zaleplon $20 \mathrm{mg}$ & 23 & 25 & -.23 & -.82 & .35 & .42 & & & & \\
\hline Zopiclone $7.5 \mathrm{mg}$ & 70 & 71 & .89 & .54 & 1.23 & .00 & & & $\rightarrow-$ & \\
\hline
\end{tabular}

Improvement Impairment

\section{6 - 17 hours after bedtime administration}

\begin{tabular}{|c|c|c|c|c|c|c|c|c|c|c|c|}
\hline & N1 & N2 & Effect & Lower & Upper & PValue & -2.00 & -1.00 & 0.00 & 1.00 & 2.00 \\
\hline Benzodiazepines - SD & 102 & 102 & .14 & -.14 & .41 & .33 & & & & & \\
\hline Benzodiazepines - DD & 83 & 83 & .57 & .26 & .88 & .00 & & & & - & \\
\hline Zopiclone $7.5 \mathrm{mg}$ & 16 & 16 & .25 & -.47 & .98 & .47 & & & & & \\
\hline
\end{tabular}

\section{4 - 6 hours after middle-of-the night administration}

\begin{tabular}{lrrrrrr}
\hline & N1 & N2 & Effect & Lower & Upper & PValue \\
Zaleplon $10 \mathrm{mg}$ & 56 & 55 & -.03 & -.40 & .35 & .89 \\
Zaleplon $20 \mathrm{mg}$ & 52 & 55 & .10 & -.29 & .48 & .61 \\
Zolpidem $10 \mathrm{mg}$ & 30 & 30 & .66 & .13 & 1.19 & .01 \\
Zolpidem $20 \mathrm{mg}$ & 30 & 30 & 1.16 & .60 & 1.72 & .00 \\
Zopliclone $7.5 \mathrm{mg}$ & 24 & 25 & 1.51 & .85 & 2.17 & .00
\end{tabular}

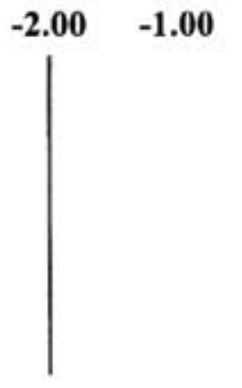

Improvement

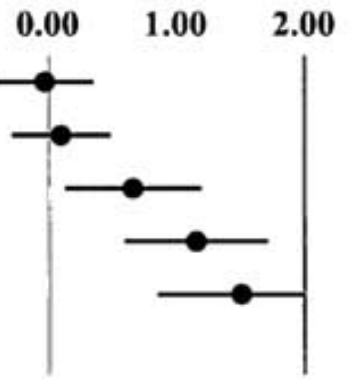

Impairment

Fig (2). Meta-analysis results.

Observed effect sizes (ranging from -2.00 to +2.00 ) and $95 \%$ confidence intervals. Significant driving impairment is found if Pvalue $<0.05$. In that case, the $95 \%$ confidence interval is greater than 0 . Abbreviations: $\mathrm{SD}=$ Single dose, $\mathrm{DD}=$ Double dose, $\mathrm{N} 1=$ treatment, $\mathrm{N} 2=$ placebo, Effect $=$ Effect size, Lower $=$ lower limit of the $95 \%$ confidence interval, Upper $=$ upper limit of the $95 \%$ confidence interval, Pvalue is significant if $\mathrm{p}<0.05$.

receptor. However, they do with a different affinity and at different subtypes of the $\mathrm{GABA}_{\mathrm{A}}$ receptor complex [26]. Zolpidem binds with high sensitivity to $\alpha_{1}-G_{A B A}$ receptors, an intermediate affinity for $\alpha_{2^{-}}$and $\alpha_{3}-\mathrm{GABA}_{\mathrm{A}}$ receptors, but has no affinity for $\alpha_{5}-\mathrm{GABA}_{\mathrm{A}}$ receptors [27]. Zaleplon also possesses high affinity for $\alpha_{1}-G_{A B A}$ receptors $\left(\alpha_{1} \beta_{2} \gamma_{2}\right)$, but is less potent that zolpidem at the $\alpha_{1^{-}}$, $\alpha_{2^{-}}$, and $\alpha_{3}-\mathrm{GABA}_{\mathrm{A}}$ receptors. In addition, zaleplon binds with greater sensitivity to $\gamma_{3}-$ and $\alpha_{5}-\mathrm{GABA}_{\mathrm{A}}$ receptors than zolpidem [28]. The impact of these differences in activity at different receptor subtypes on the magnitude and duration of (residual) drug activity needs to be addressed by future research. 
The observed driving impairment with benzodiazepines is in line with the significantly increased risk of traffic accidents reported by the majority [29-31], but not all $[32,33]$ epidemiological studies examining benzodiazepine used for hypnotic purposes. A significantly increased risk of traffic accidents has also been reported for zopiclone [31].

Higher blood concentrations of benzodiazepines, either used for hypnotic [31] or anxiolytic purposes [34], produce significantly higher traffic accident risks when compared to the risks observed when administering the recommended dose. Although not found in elderly [30], recent epidemiological evidence confirmed that the blood concentration of benzodiazepines was significantly related to impairment in apprehended drivers [35].

Epidemiological data on zolpidem and zaleplon is currently lacking.

\section{Limitations of Current Research and Future Aims}

A first limitation of the presented analyses is that the driving tests were performed after 1 or 2 nights of administration. It can therefore be argued that the presented results do not take into account that tolerance to the performance impairing effects may develop after repeated use of hypnotics. However, tolerance to the effects of benzodiazepines develops slowly: significantly increased traffic accident risks have been reported to last from several weeks [29] up to 1 year after treatment initiation [30]. Future driving studies should aim to determine the effects of longterm use of hypnotics on driving performance and whether tolerance develops to the impairing effects of benzodiazepines and zopiclone.

Secondly, all on-the-road studies were performed in healthy adults. In real life, elderly patients are the most frequent users of hypnotics. Taking into account that elderly are the fast-growing segment of the general population who increasingly depend on the ability to drive a car to maintain their independence, future driving studies should aim at studying the effects of hypnotics in elderly patients. The onthe-road driving test is performed on a public highway. Although this test is regarded as the 'gold standard' method to determine driving ability during normal traffic, other onthe-road tests have been developed over the years, including car-following tests and city driving. Studies applying these tests are limited and were not included in the meta-analysis, since the latter two tests examine different driving skills (and have different outcome measures than SDLP) when compared to highway driving. For example, highway driving is a relatively monotonous vigilance task using SDLP as primary parameter, whereas city driving requires higher attentional demands to ensure vehicle control and has a subjective driving performance score as outcome measure.

Limitations of the meta-analysis include the relatively low number of driving studies that were available for statistical analysis. In addition, because meta-analysis does not allow including more than one treatment-versus-placebo condition from each study, for some analyses, a choice had to be made between different treatment-versus-placebo conditions. However, additional analyses replacing the used conditions by those conditions that were left out showed that this did not affect the overall results of the meta-analyses.

\section{CONCLUSION}

The clinical implications resulting from these metaanalyses are that patients should be warned that their driving ability may be impaired when using benzodiazepine hypnotics or zopiclone. With regard to traffic safety, zolpidem and especially zaleplon are safe alternatives for patients who want to drive a car.

\section{REFERENCES}

[1] National Sleep Foundation. 2002 Sleep in America Poll. Washington, U.S.A., 2002.

[2] Roth T, Ancoli-Israel S. Daytime consequences and correlates of insomnia in the United States: results from the 1991 National Sleep Foundation Survey II. Sleep 1999; 22 (suppl.2):S354-358.

[3] Ancoli-Israel S, Roth T. Characteristics of insomnia in the United States: results from the 1991 National Sleep Foundation Survey I. Sleep 1999; 22 (suppl. 2):S347-353.

[4] O'Hanlon JF, Haak TW, Blaauw GJ, Riemersma JBJ. Diazepam impairs lateral position control in highway driving. Science 1982; 217: 79-81.

[5] Verster JC. Measurement of the effects of psychoactive drugs on driving ability and related psychological processes. Thesis. Utrecht, The Netherlands, 2002.

[6] Verster JC, Veldhuijzen DS, Volkerts ER. Residual effects of sleep medication on driving ability. Sleep Med Rev 2004; 8:309-325.

[7] Lipsey MW, Wilson DB. Practical meta-analysis. Applied Social Research Methods Series, Volume 49. Sage Publications, Inc. 2001.

[8] Louwerens JW, Gloerich ABM, De Vries G, Brookhuis KA, O'Hanlon JF. In: Noordzij PC, Roszbach R Eds, The relationship between drivers' blood alcohol concentration (BAC) and actual driving performance during high speed travel. Alcohol, Drugs and Traffic Safety. Amsterdam, Excerpta Medica. 1987; 183-192.

[9] Borenstein M, Rothstein H. Comprehensive Meta-analysis. A computer program for research synthesis. Biostat, Inc. USA, 1999.

[10] O' Hanlon JF. Driving performance under the influence of drugs: rationale for, and application of, a new test. Br J Clin Pharmacol 1984; 18: 121S-129S. [Study 1 and 2].

[11] Volkerts ER, Louwerens JW, Gloerich ABM, et al. Zopiclone's residual effect upon actual driving performance versus those of nitrazepam and flunitrazepam. VSC, Report 84-10, Traffic Research Centre, Groningen, The Netherlands, 1984. [Study 3].

[12] O'Hanlon JF, Volkerts ER. Hypnotics and actual driving ability. Acta Psychiatr Scand 1986; 74 (Suppl 332): 95-104. [Study 4].

[13] Brookhuis KA, Volkerts ER, O'Hanlon JF. Repeated dose effects of lormetazepam and flurazepam upon driving performance. Eur $\mathrm{J}$ Clin Pharmacol 1990; 38: 1-5. [Study 5].

[14] Volkerts ER, van Laar MW, van Willigenburg APP, Plomp TA, Maes RAA. A comparative study of on-the-road and simulated driving performance after nocturnal treatment with lormetazepam 1 $\mathrm{mg}$ and oxazepam $50 \mathrm{mg}$. Hum Psychopharmacol 1992; 7: 297309. [Study 6].

[15] Vermeeren A, O'Hanlon JF, DeClerck AC, Kho L. Acute effects of zolpidem and flunitrazepam on sleep, memory and driving performance, compared to those of partial sleep deprivation and placebo. Acta Ther 1995; 21: 47-64. [Study 7].

[16] Vermeeren A, Danjou PE, O'Hanlon JF. Residual effects of evening and middle-of-the-night administration of zaleplon 10 and $20 \mathrm{mg}$ on memory and actual driving performance. Hum Psychopharmacol Clin Exp 1998; 13: S98-S107. [Study 8].

[17] Vermeeren A, Riedel WJ, van Boxtel MPJ, et al. Differential residual effects of zaleplon and zopiclone on actual driving: a comparison with a low dose of ethanol. Sleep 2002; 25: 224-231. [Study 9].

[18] Verster JC, Volkerts ER, Schreuder AHCML, et al. Residual effects of middle-of-the-night administration of zaleplon and zolpidem on driving ability, memory functions and psychomotor performance. J Clin Psychopharmacol 2002; 22: 576-583. [Study $10]$.

[19] Volkerts ER, de Vries G, Meijer T, O'Hanlon JF. Driving performance the day after use of loprazolam, flunitrazepam and placebo. Traffic Research Centre, University of Groningen, The Netherlands. VK 83-04, 1984. [Study 2]. 
[20] O'Hanlon JF, Volkerts ER, Brookhuis KA, et al. Repeated dose effects of nitrazepam and temazepam upon actual driving performance. Traffic Research Centre, University of Utrecht, The Netherlands. VK 85-02, 1985. [Study 4].

[21] Brookhuis KA, Volkerts ER, O'Hanlon JF. Repeated dose effects of lormetazepam 1 and $2 \mathrm{mg}$ (in soft gelatine capsules) and flurazepam $30 \mathrm{mg}$ upon driving performance. Trafic Research Centre, University of Groningen, The Netherlands. VK 86-18, 1986. [Study 5].

[22] Volkerts ER, Abbink F, van Laar MW, Plomp TA. A double-blind study to compare the acute residual effects of lormetazepam $1 \mathrm{mg}$, oxazepam $50 \mathrm{mg}$ and placebo on driving performance in an overthe-road driving test. NIDDR, University of Utrecht, The Netherlands, 1989. [Study 6].

[23] Van Laar MW, Volkerts ER. Driving and benzodiazepine use. Evidence that they do not mix. CNS Drugs 1998; 10: 383-396.

[24] Vermeeren A. Residual effects of hypnotics: epidemiology and clinical implications. CNS Drugs 2004; 18: 297-328.

[25] Longo MC, Lokan RJ, White JM. The relationship between blood benzodiazepine concentration and vehicle crash culpability. J Traffic Med 2001; 29:36-43.

[26] Dämgen K, Luddens $H$. Zaleplon displays a selectivity to recombinant $\mathrm{GABA}_{\mathrm{A}}$ receptors different from zolpidem, zopiclone and benzodiazepines. Neurosci Res Commun 1999; 25:139-445.

[27] Crestani F, Martin JR, Möhler H, Rudolph U. Mechanism of action of the hypnotic zolpidem in vivo. Br J Pharmacol 2000; 131:12511254 .
[28] Sanna E, Busonero F, Talani G, et al. Comparison of the effects of zaleplon, zolpidem, and triazolam at various $\mathrm{GABA}_{\mathrm{A}}$ receptor subtypes. Eur J Pharmacol 2002; 451:103-110.

[29] Neutel CI. Risk of traffic accident injury after a prescription for a benzodiazepine. Ann Epidemiol 1995; 5: 239-244.

[30] Hemmelgarn B, Suissa S, Huang A, Boivin J-F, Pinard G. Benzodiazepine use and the risk of motor vehicle crash in the elderly. JAMA 1997; 278: 27-31

[31] Barbone F, McMahon AD, Davey PG, et al. Association of roadtraffic accidents with benzodiazepine use. The Lancet 1998; 352: 1331-1336.

[32] Leveille SG, Buchner DM, Koepsell TD, McCloskey LW, Wolf ME, Wagner EH. Psychoactive medications and injurious motor vehicle collisions involving older drivers. Epidemiol 1994; 5:591598.

[33] McGwin G, Sims RV, Pulley L, Roseman JM. Relationship among chronic medical conditions, medications, and automobile crashes in the elderly: a population-based case-control study. Am J Epidemiol 2000; 152:424-431.

[34] Ray WA, Fought RL, Decker MD. Psychoactive drugs and the risk of injurious motor vehicle crashes in elderly drivers. Am J Epidemiol 1992; 136:873-883.

[35] Bramness JG, Skurtveit S, Mørland J. Clinical impairment of benzodiazepines - relation between benzodiazepine concentrations and impairment in apprehended drivers. Drugs \& Alcohol Dependence 2002; 68:131-141. 